\title{
JAN SOKOL'S APPROACH TO THE RENEWAL OF MONUMENTS WITH AN EMPHASIS ON HIS ACTIVITIES AT PRAGUE CASTLE
}

\author{
Martin Šnorbert
}

\author{
Czech Technical University in Prague, Faculty of Civil Engineering, Department of \\ Architecture, Thákurova 7, 16629 Prague 6 - Dejvice, Czech Republic; \\ martin.snorbert@fsv.cvut.cz
}

\begin{abstract}
This contribution deals with the approach of the architect Jan Sokol to the renovation of monuments within his architectural work. Close attention is paid to the biographical part, as it describes the development of the architect's relation to the history of art and cultural heritage of previous generations. Personalities who influenced him during his studies, but also during architectural practice, are mentioned. It also captures the period when Sokol worked as an employee in a state studio which was focused on the preservation and restoration of monuments. Subsequently, selected buildings and projects designed by this architect in the field of historic preservation are discussed. Of these, the most emphasized are the projects which were created for the area of Prague Castle. To understand these projects, the preserved texts, plans and ideas of the author are used. Unfortunately, many of the discussed projects were not implemented, but they are very valuable in their thought form. And this is one of the reasons why this article iss written, it tries to show the quality of Sokol's projects. Furthermore, the purpose is to point out the personality of the architect, who has not been fully appreciated yet, nevertheless he has inspired several of his students and other architects. In conclusion, it is pointed out that the Sokol's discussed approach was based on a deep knowledge of the construction of the historical buildings and history of art, and that led him to approach to these buildings with a certain humbleness. It is further stated that the architect Jan Sokol was a generally gifted author with an overlap into fields areas.
\end{abstract}

\section{KEYWORDS}

Architect Jan Sokol, Historic preservation, Town planning, Prague Castle, Romanesque Palace in Olomouc, St. Vitus Cathedral, Pinkas Synagogue

\section{INTRODUCTION}

As a part of my doctoral dissertation, I deal with the topic of architectural interventions in the area of Prague Castle in the second half of the 20th century. While studying the materials, I was interested in the name and the work of Jan Sokol, who I wanted to find out more about. About the projects of a man who did not adapt to the taste of his period but kept his distinctive approach. About an architect, whose significance for the Czech architecture after World War II has not been fully appreciated yet by the non-professional public, but also by some experts.

Sokol's personal memories, texts and plans, which were arranged and published in book form, helped me understand the researched topic. His son Václav had the main credit for publishing the book. Doctoral dissertation by Karin Urbanová Kasanová was used as another source of information. Several articles in professional periodicals were also dedicated to Sokol. 
CIVIL

ENGINEERING

THE CIVIL ENGINEERING JOURNAL 1-2021

\section{LIFE AND STUDIES}

Jan Sokol was born on May 24, 1904 in Roudnice nad Labem, but his family moved relatively soon to Náchod, where Jan lived out his youth and adolescence. He spent most of the time during the holidays in Jablonné v Podještědí, where his uncle worked as a chaplain. He graduated from the grammar school in Náchod and then he decided to study architecture at the Czech Technical University in Prague.

He was not completely satisfied with the style of teaching (the core of architecture - design was not introduced until the third year of study). During last two years, he studied and prepared the final work under the guidance of architect Antonín Engel. Although he lectured poorly, according to Sokol, he acknowledged him and very gratefully thought back to a month-long study stay in Italy, for which he was selected together with 19 other students. Not only this, but also the fact that Engel wrote him a recommendation after graduation, shows the fact that Sokol was a good and careful student, whom Engel liked. However, Sokol did not want to continue in this kind of classicism, which he adhered to in his last works due to his teacher.

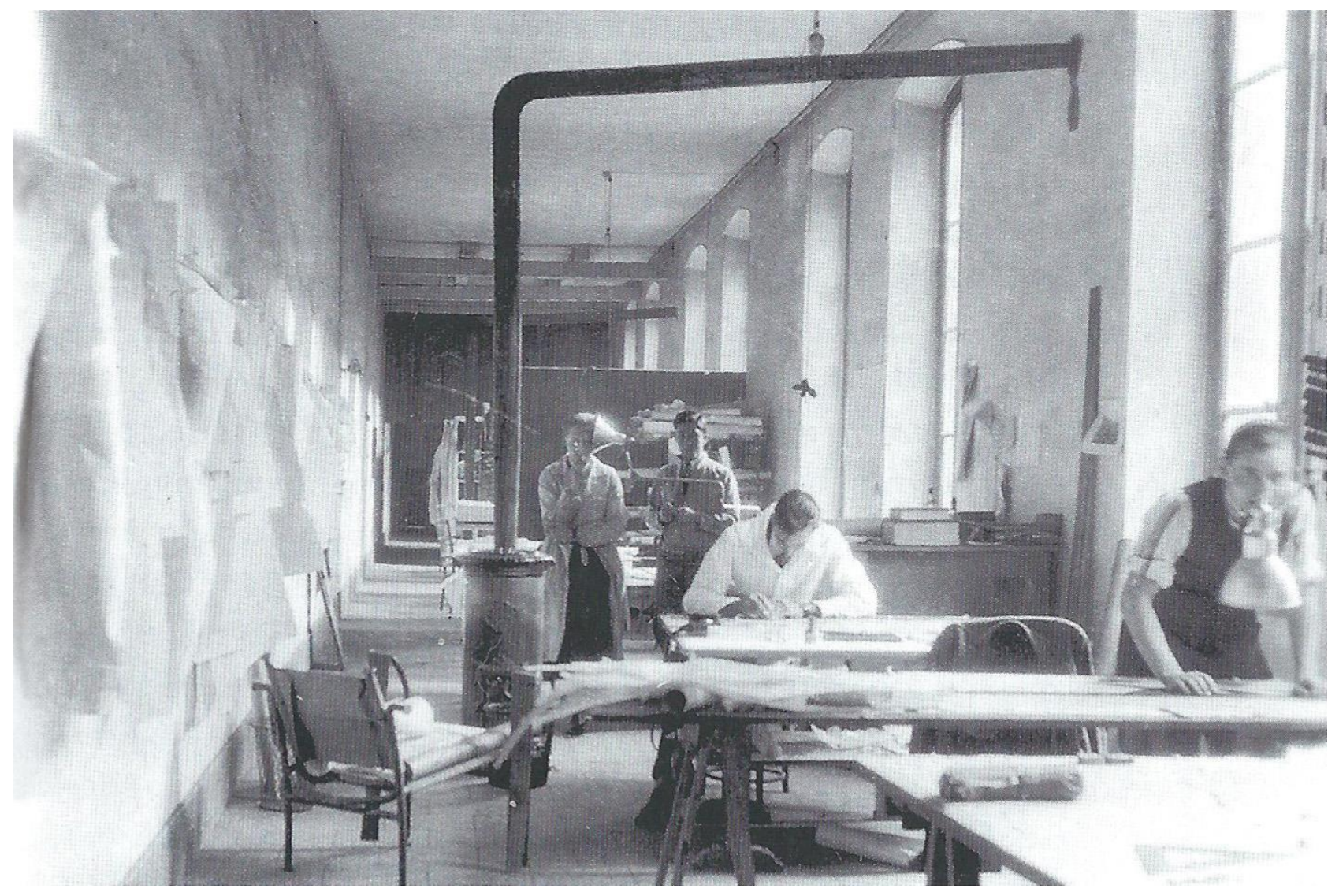

Fig. 1 - Working environment in the studio of Le Corbusier in Paris [1]

A one-year scholarship in France was very important and instructive. He studied at the École des Beaux-Arts and even he got into the studio of Le Corbusier. He worked here, for example, on the project of Villa Savoy or on the palace Tsentrosoyuz. He later wrote this down: "Le Corbusier was a great artist, which is why his buildings were so impressive. (...) August Perret was in this activity (in searching of the impulse for a new architecture - author's note) further than Le Corbusier, nevertheless he did not abandon the classical tradition, still did not achieve the impressive modernity of Le Corbusier. At one time it seemed to me that he was right and that I should have worked with him, but in the end I saw that all I should do was to try to find myself and look for advice, not an example of others."[2] In Paris he established contacts with many Czech 
personalities, for example, the philosopher Jan Patočka, the painter František Kupka or the composer Bohuslav Martinů. Professor Vojtěch Birnbaum ${ }^{1}$ also arrived in France to see Sokol. And when Gočár arrived in Paris, he invited Sokol to be his guide, because he heard that Sokol had worked for Le Corbusier. After returning home, he was offered the opportunity to spend another year in France, but he decided to go to England (after consulting with Prof. Wirth ${ }^{2}$ ), because he wanted to get acquainted with urbanism in theory and practice. He visited London, Edinburgh, Birmingham. He returned to Czechoslovakia via Rotterdam, Amsterdam, Frankfurt, Dessau, Berlin and Dresden.

He returned to Prague, but unfortunately during the financial crisis, so the promise of a job in Gočár's studio did not come off, nevertheless Gočár became an important person during this period, as Sokol was able to study at his school (which did not contribute to Sokol's popularity at CTU). In cooperation with Emanuel Hruška, they made a good name for themselves in several town planning competitions, in which they placed in award-winning places. In order to ensure himself a permanent salary, he was employed at the Ministry of Public Works as a contract architect. From the beginning this work did not satisfied him, because he was more of a clerk than the architect. Eventually, he found an interesting content of work, which consisted in finding land for state buildings, assigning projects. Some of them he could even draw in advance. In 1939 he became a professor of style at the Academy of Arts, Architecture and Design in Prague (he had previously worked there as an associate professor) and from 1941 to 1945 he worked as a rector there. He took over the leadership of the school after Otakar Novotný, because in the mentioned year 1941, a large part of the original professors was retired in order to make positions for teachers who were coming from the resigned border. The attempt to return these professors after the war then brought considerable problems and difficulties. They were joined by an investigation because he served under a relatively high position during the Protectorate. In connection with the rise of the communists to power, Sokol as Catholic began to be unpopular, became undesirable at school, which led to the dissolution of his school (studio) at the Academy of Arts, Architecture and Design in 1951, but until the final end at 1959 he had lectures about style. After these events, he began working in the historic preservation and in SÚRPMO ${ }^{3}$, which enabled him to work again at Prague Castle. Especially before the war, it was true that whoever wanted to participate in competitions had to belong to some association. Sokol joined the two - the Club of Architects, which was associated with the magazine Stavba and from the beginning with the chairman Oldřich Starý. The second was the Mánes art association and he valued it more. He met many important architects there and other artists. Sokol died, after a long and interesting life with many vicissitudes, on September 27, 1987.

\section{SOKOL AND HISTORIC PRESERVATION}

Sokol was already interested in monuments, and especially in the history of art, while he studied at university. He enrolled at Charles University for an art history course as an extraordinary student. The following year he attended lectures and seminars in a small group of future art

\footnotetext{
${ }^{1}$ Vojtěch Birnbaum (7.1.1877 - 30.5.1934) was a Czech historian and art theorist, university teacher, he also devoted himself to historic preservation.

2 Zdeněk Wirth (August 11, 1878 - February 26, 1961) was a Czech art historian, one of the founders of historic preservation, a university teacher, an academic of the Czechoslovak Academy of Sciences and a founding member of the Club for Old Prague.

${ }^{3}$ The State Institute for the Reconstruction of Historic Towns and Buildings (SÚRPMO) was a state institute, which was established in 1954 as a centralized workplace for a comprehensive solution for the reconstruction of historic city centres in Czechoslovakia (following the $\mathrm{R}$ - studio at Stavoprojekt existing since 1949). After 1989, there was a gradual decline in activity.
} 
historians. He was very pleased that Josef $\mathrm{Cibulka}^{4}$, a professor at the Faculty of Theology, began lecturing art history at Czech Technical University. Sokol had known him from earlier times thanks to his uncle, who worked as a priest in Jablonné nad Orlicí and asked Cibulka for advice about painting the church (in addition, Cibulka was a native of nearby Ústí nad Orlicí). This teacher had a great influence on Sokol and recommended him to join the Club for Old Prague and to the seminars of Professor Birnbaum. Birnbaum did not accept beginners, but Sokol succeeded through an intercession from Cibulka. From 1924 to 1926, Sokol and Cibulka prepared an inventory of Lanškroun monuments for the Czech Academy.

Sokol also dealt with these topics during his pedagogical work at the Academy of Arts, Architecture and Design in Prague. After a not very pleasant ending at school, he received an offer for a position at SÚPPOP ${ }^{5}$. Sokol took a long time to think, because he was always close to the monuments (see described above), but he was afraid that the work in the historic preservation was filled mainly with clerical tasks but scientific work with semi-creative practice was disappearing. The staffing was not ideal either, because young and inexperienced historians came to the fore. Sokol would rather have joined one of the design institutes - he was thinking especially of the Institute of Reconstruction, which was led by Vilém Lorenc. ${ }^{6}$ Unfortunately, he did not get there due to the inability of the ministry and the Union of Architects to stand up for Sokol. Eventually, Sokol decided to accept the offer. The work in the historic preservation was considered as a quiet office, but it will be shown from the following examples of Sokol's works and projects that this consideration was not true. In the words of the professor Sokol: "He (Preservationist - author's note) must defend an idea that is rarely understood and even less ever shared against the attack of the ignorant and unconscious majority, which has always been here, but now had all the power in its hands. Most of this majority often included own monument authorities on national committees, whose persuasion and even swearing had to be considered." [3]

In the 1960s, Sokol took part in the adaptation of the Old Palace of Prague Castle, he was asked to create a relatively extensive study, and therefore Gočár suggested him that he should enter a design institute due to the scope of this task. Sokol agreed but told Gočár that he had recently applied for a position at SÚRPMO. However, the director had rejected him because of the personnel reference. Gočár decided to intercede for Sokol and thus began Sokol's work in SÚRPMO. He ended his work at this institute in the first half of the 1970s, after that he designed only smaller contracts under his own name.

\section{Modifications of the Strahov Monastery for the Monument of National Literature}

Even before joining SÚPPOP, Sokol received an assignment from the Ministry of Education for the reconstruction of the Strahov Monastery in Prague, which was empty due to the dissolution of religious orders (including Strahov Premonstratensian Order), internment and imprisonment of many ecclesiastic representatives. The previous amateur experiment reached a deadlock, and therefore professional guidance was required, which was provided by Professor Sokol. He came into conflict with employees of the communist ecclesiastical office. For example, the capitular hall was rebuilt into a vestibule, but during this event, some underground canals were destroyed.

\footnotetext{
${ }^{4}$ Josef Cibulka (July 1, 1886 - April 2, 1968) was a Czech art historian and archaeologist focused on the history of religious art and medieval archeology, a university teacher and a Roman Catholic priest.

5 The State Institute of Monument Care and Nature Protection (SÚPPOP) was a Czechoslovak institute under the Ministry of Education (respectively culture), established in 1958 and based on the Act on Cultural Monuments (No. 22/1958 Coll.). It ran until 1990.

6 Vilém Lorenc (March 21, 1905 - April 1, 1978) was a Czech architect, preservationist and town planner, one of the initiators of the establishment of the State Institute for the Reconstruction of Historic Towns and Buildings (SÚRPMO).
} 
These canals drained water from underground springs, which Sokol pointed out. As a result of this destruction, soil movements took place and groundwater had to be captured again and drinking water had to be drained into the sewer at vast expense. On the other hand, Sokol appreciated that he could create a working group composed of his students at the Academy of Arts, Architecture and Design in Prague. The teaching therefore took place in situ, directly in connection with the implementation and students could involve in all aspects of the architect's work (supervision of craftsmen, administrative tasks, solving construction details and problems on the construction site).

\section{Reconstruction of the Town Cheb}

Very soon after taking office, he was entrusted with the management of the monumental reconstruction of the town Cheb. It was a government task with an extremely short completion date. Josef Pošmourný ${ }^{7}$ was originally entrusted with this task. He tried to meet the deadline, probably not entirely in legal ways, for which he was removed and even imprisoned (in the end it turned out that it was caused by his "building enthusiasm"). Every month, during the inspection day, Sokol fought battles with representatives of the company that carried out the reconstruction, but at the same time this company did not have adequate qualifications to carry it out. In addition, they were mainly interested in the financial side of the whole thing and to accomplish the reconstruction as soon as possible. Except for his experience as an architect, Sokol was also able to use his historical knowledge - he was concerned with the development of a complex urban plan of the entire town and Cheb Castle.

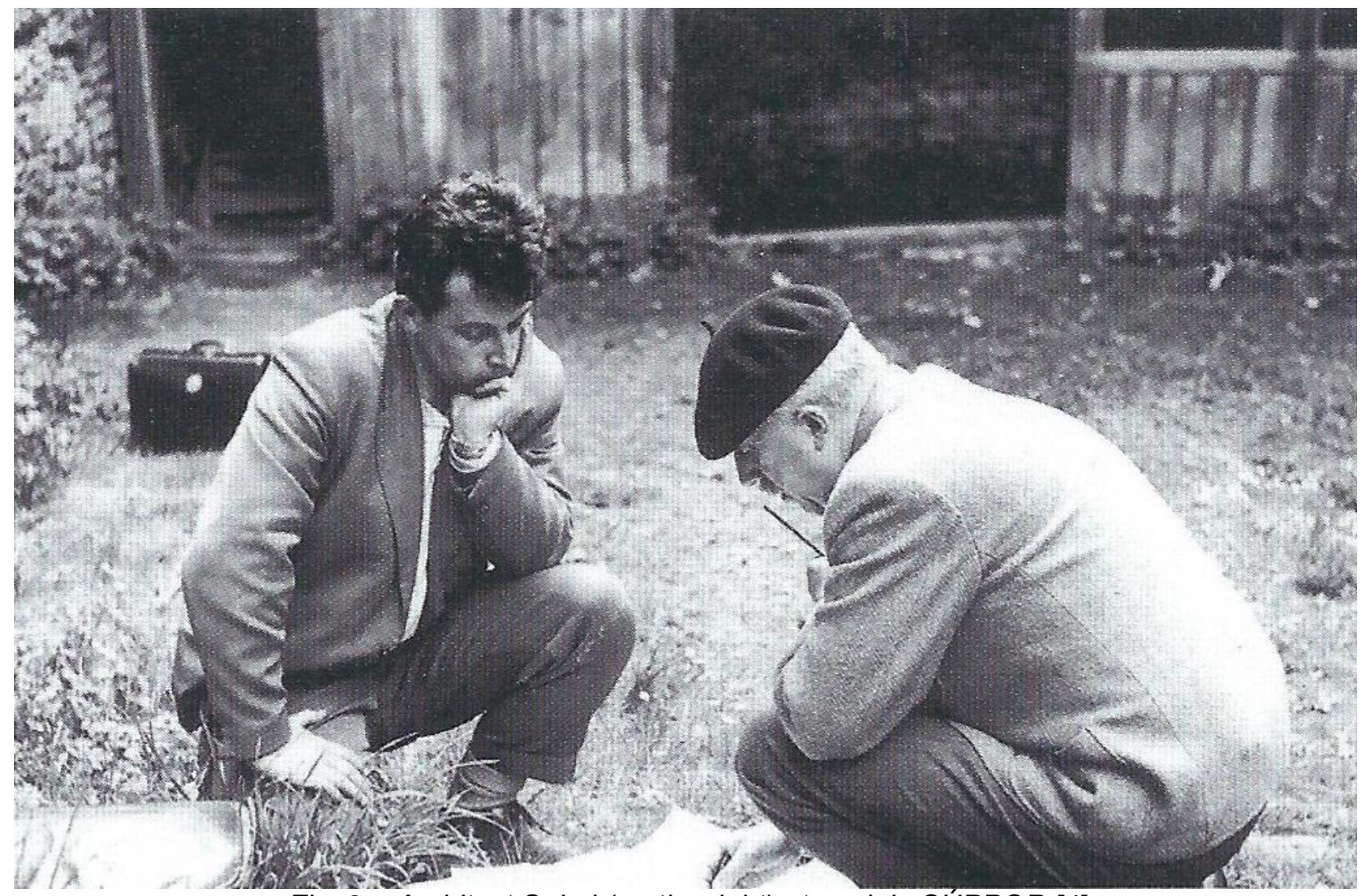

Fig. 2 - Architect Sokol (on the right) at work in SÚPPOP [4]

7 Josef Pošmourný (March 8, 1910 - February 21, 1974) was a Czech architect, preservationist, administrative officer, art historian and university teacher. 


\section{Renovation of a Romanesque Palace in Olomouc}

One of the other tasks was to renovate and adapt the remains of the Premyslid Palace in Olomouc, but according to Sokol, it was a bishop's palace built in the Romanesque period. It was difficult to define the extent of what belongs to the palace in this taskn. He also tried to ensure that the visitor's flow of this monument did not limit the operation and function of the adjacent church. The following spaces were finally declared as a national monument: The Gothic gallery with decorative Romanesque windows, the chapel of St. Anna and St. John and the round tower. Quite surprisingly, there was also a clash with the local chapter. This ecclesiastical office did not have much understanding for Sokol's efforts to seek a compromise in operational matters, and unfortunately even the canons did not fully understand the artistic value of this palace. Making the windows accessible required a relatively large intervention in the valuable Gothic complex, as it was necessary to raise the roof frame above the north and west wings. Sokol figured out a very ingenious and effective solution, supported by a footbridge, which allowed movement around the entire perimeter of the Gothic gallery, while people could see the Romanesque remains at a certain distance. There were delays and changes caused by historical and construction research, and Sokol had to complete detailed plans in his new work at SÚRPMO. The construction slowed down further, and work was eventually halted for several years due to archaeological research, after which the necessary activity was no longer carried out and a lack of funding meant that the modification was not completely finished. Sokol gained a negative but valuable experience from this project.
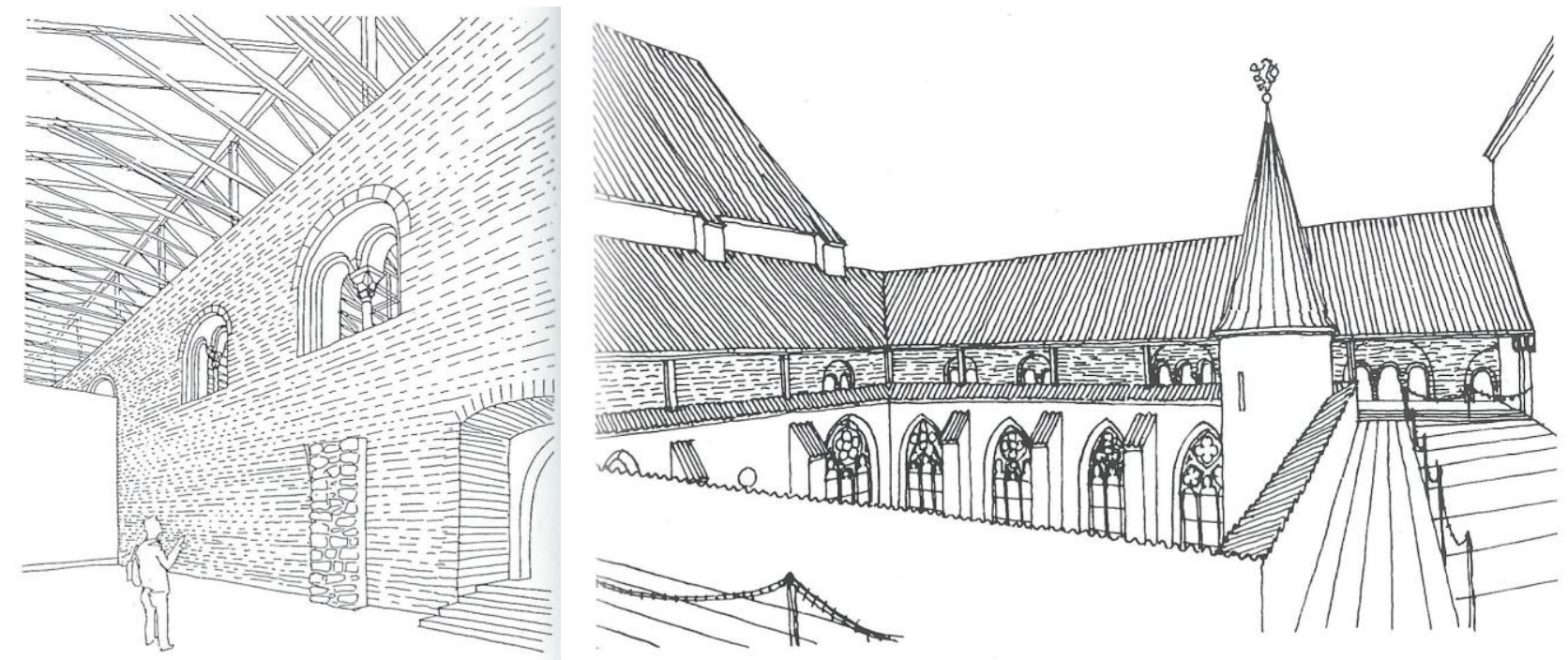

Fig. 3 and 4-Plans for the modification of the bishop's palace in Olomouc [5]

\section{Pinkas Synagogue}

In 1951, a new challenge appeared. It concerned the modification of the Pinkas Synagogue and the modification of its immediate surroundings. This synagogue was built in the late Gothic period (more precisely in 1535) and had gone through several modifications over the centuries. The task was to design the conversion of the synagogue into a memorial to the Jewish victims of the Holocaust. The difficulty was that this important building was the last remnant and evidence of older buildings. It was therefore necessary to integrate the synagogue into a broader context with the surroundings. He could have proved his urban skills here. He tried to connect the building itself as much as possible with the neighbouring cemetery and the buildings on it. He wanted to create a coherent complex of the Jewish ghetto. He intended to reduce traffic in Josefovská Street to one lane and move the other to Kaprova Street, which is wider. This solution would allow a small zone 
with the level of the original street to be preserved around the synagogue. His intension was to create a dignified space between the synagogue and the cemetery wall, from which a new main entrance to the synagogue would lead. In the second phase, he focused on interior design. Remains of the original glazed plaster have been preserved in the synagogue hall, which had to be cleaned and completed. The names of the dead Jews should be written in red on the walls and arches. In the end, this idea was realized quite differently - the text was not written as a human hand, but in a neat artistic font and was written in new wet plaster, so the durability of the inscriptions was very low. As with the previous project, the implementation of the adaptations was delayed, mainly due to the international political relations of the Soviet republics with the state of Israel. Work on revitalization did not begin until the 1960s, and the resulting (current) state underwent many changes compared to Sokol's design. There were more author teams, and today it is difficult to recognize which modifications are at least the mental work of the professor.

\section{SOKOL AND PRAGUE CASTLE}

Sokol gained his first knowledge about the area of Prague Castle while he was studying with future art historians as part of his studies at Charles University. Together with other students, they often visited the Castle and observed from the outside the progress of work on the reconstruction of this area. Through his uncle, he met the castle builder Fiala ${ }^{8}$ and even helped the architect with drawing of plans on weekends.

Even on a personal family level, Sokol has always been close to the Castle, and therefore close to the presidents of the First Republic. His great-aunt Anna Černá, who originally ran the kitchen in Vienna by Professor Albert and was acquainted with the family of President Masaryk. The first President appointed her shortly as a housekeeper at Prague Castle and later at Lány Castle. Sokol's aunt also had contact with Mrs. Masaryk and her daughter Alice. All this resulted in two visits of Sokol in Lány - once he spent a weekend there with his brother and the second opportunity was in 1934, when he had lunch with his future wife and with the president. Masaryk left a great impression on him. As a part of his work at the Castle in 1936-1939, he often met President Beneš. During this period, Pavel Janák became the official castle architect. He decided to create a larger design group, which would consist of an architect (Janák), a town planner (Sokol) and a landscape architect (Fierlinger ${ }^{9}$ ). Janák realized that it was necessary not only to solve the modifications of the Castle itself, but also the wider surroundings, especially the northern area which was formed mainly by gardens. After the communist coup, Sokol was ignored due to the Catholic faith and did not continue the work on the Castle until the second half of the 1960s and in the 1970s.

\section{First Activities at Prague Castle (1936 - 1939)}

Sokol was a part of the design team, led by architect Janák. Any disagreements were resolved by a commission of experts led by President Beneš. First, they dealt with the renovation of Queen Anne's Summer Palace and the adjacent garden, on the occasion of the PEN International's congress, which should take place here in 1938. The first clashes occurred very early, mainly because Fierlinger had no sense for history and wanted to modify the garden in the

\footnotetext{
${ }^{8}$ Karel Fiala (November 29, 1862 - April 3, 1939) was a Czech architect, conservator, who significantly contributed to the construction - historical research, modifications and completion of Prague Castle and some other monuments.

${ }_{9}^{9}$ Otakar Fierlinger (May 21, 1888 - September 8, 1941) was a Czech landscape architect and town planner. His brother was the politician Zdeněk Fierlinger who was the Prime Minister of Czechoslovakia in the years 1945 - 1946.
} 
park style of the 18th century using floral embroidery and buksus edging. On the other hand, Sokol, but also Janák, promoted a flower garden that would better correspond to the time of formation of the Belvedere. Fierlinger was joined by gardeners because they found the architects' solution more laborious and expensive. The architects enforced their version, but only briefly. After all the ups and downs, the gardeners eventually overcame the resistance and implemented their project. At this time, the castle property also included the Hvězda Summer House and the surrounding area. The considered adjustments were another source of disagreement. Janák wanted the surroundings of the Renaissance summer house to have the form of a game preserve, while Fierlinger promoted the park and the star pool in front of the summer house with a fountain. Janák won this dispute. Sometimes disagreements were discussed at the construction committee, where Janák and Sokol were defended by Zdeněk Wirth, and Fierlinger and Beneš's advisers Strimpl and Stretti-Zamponi - stood in opposition to them. In most cases, Beneš preferred the solution of architects. Another project in this period was the extension of the road on the Marian walls to the west along the castle and Lumbe's gardens, while the road led to Pohořelec.

Sokol had relatively good memories of Beneš, and since he could have known Masaryk before, he mentioned in his memoirs a comparison of these first Czechoslovak presidents in relation to art: "Both presidents were not very interested in art, especially fine arts. Masaryk chose a man he trusted, and then he didnnot care about anything anymore, he gave him a free hand. Beneš had similar attitude, but he did not give up his participation. He went to exhibitions diligently.'[6]

\section{Pre-war tasks in churches in the area of Prague Castle}

Sokol collaborated in this field mainly with the sculptor Josef Wagner ${ }^{10}$. In 1935, canon Švec, who worked in the Basilica of St. George asked Sokol to create a project for a new main altar, because until then the existing one was assembled from various parts and was therefore not perceived as definitive. The task was to design an altar that would not be too heavy, but at the same time to be concise and monumental. He solved a mensa without an altar extension, a Renaissance sanctuary in the wall should be used as a tabernacle. This required that the altar must be high enough so that it would not be lost when it would be viewed from the nave. Sokol designed four steps leading to the mensa, then tall candlesticks and a cross to make the whole table stand out. In the first design, metal candlesticks and a cross, a stone altar plate and other elements of wood were considered. Wood was not popular by preservationists (they were afraid that it would rot soon), so the second design included a table made of bronze sheet metal and a wrought relief of an altarpiece. There were some problems - the stairs needed iron reinforcement, which did not correspond to Sokol's idea of technical purity, Wagner preferred the modelled relief to the wrought iron. A snag also appeared during the construction, as it was not possible to get a bronze sheet of the appropriate thickness to make the tablecloth of the altar self-supporting, so the iron reinforcement had to be used again as for the stairs. The shape of the altar was thus preserved, but with certain concessions, in addition, Wagner's modelled relief then contrasted even more with the construction. That is why Sokol did not feel a lot of regret when the altar was removed by the Germans at the beginning of the protectorate.

The second important common project was the competition for the tomb of St. Adalbert. The place for this tomb was determined because of the historical situation, it was not considered that the cathedral also serves as a place of worship, which would be greatly devalued by a large tombstone in the middle. Sokol tried to create a certain sacredness of the tomb, although in the competition assignment he felt that a monument to a historical figure was expected rather than the

10 Josef Wagner (March 2, 1901 - February 10, 1957) was a Czech sculptor and draughtsman, a disciple of Jan Štursa and Josef Mařatka, and a professor at the School of Arts and Crafts in Prague. 
tomb of a Catholic saint. Wagner understood his idea and they worked together intensively for several months. Nevertheless, they did not win the competition, because the chairman of the jury was Professor Matějček ${ }^{11}$. Although he claimed to be a follower of modern art, he actually supported the art of the 19th century. In the end, he pushed through the design of the sculptor Vobišová and the work was immediately assigned to her, but it was not implemented in this period. ${ }^{12}$ During the Second Republic, another competition was announced for the silver tomb of St. Wenceslas. Sokol and Wagner participated again, although the character of this competition was different, because it was the completion of a tomb, which was started by the architect Kamil Hilbert. Again, both authors emphasized the sanctity of the tomb. The grave looked like a flat coffin carried by a group of angels modelled by Wagner. Unfortunately, they failed again, Matějček preferred a banal tomb of historical shape which was covered with reliefs.

Fig. 5 and 6 - Altar in the Basilica of St. George [7] and model of the tomb of St. Adalbert [8]
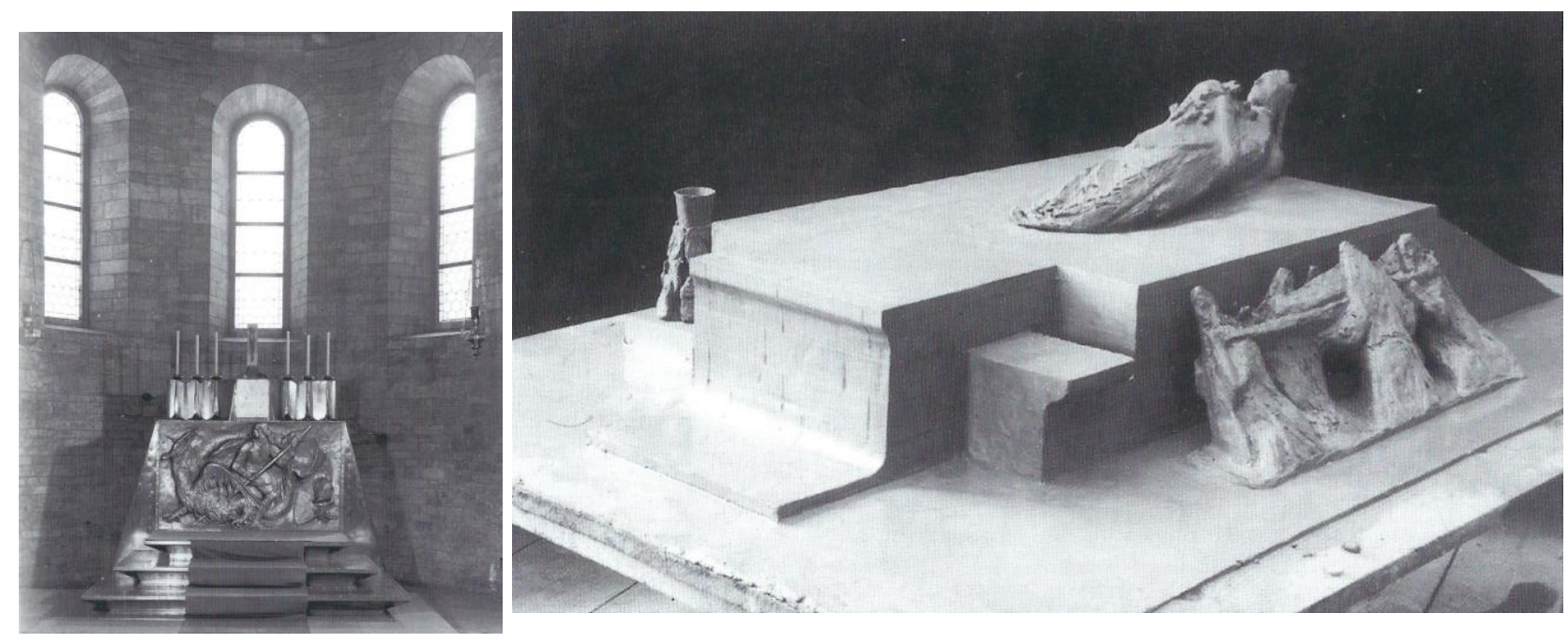

\section{Door and Vestibule of the Golden Gate}

After WWII in 1946, another competition was announced within the Cathedral of St. Vitus, Wenceslas and Adalbert. Sokol and Wagner finally won this competition. It was about the door of the Golden Gate. The solution soon turned into a challenging architectural task. It was not specified in which of the openings the door should be hung, whether in the double outer or inner. Practical reasons then required the creation of a vestibule, which could form a disruptive element from the inside. Originally, the competition was announced for a narrower group of several sculptors, to which Wagner was invited. He accepted it on the condition that he would work with an architect (Sokol), because he considered this task primarily as an architectural task. The first

\footnotetext{
11 Antonín Matějček (January 31, 1889 - August 17, 1950) was a Czech art historian, professor at Charles University, and lectured at the Academy of Arts, Architecture and Design in Prague and at the Academy of Fine Arts. He dealt mainly with Czech art of the Gothic period and the 19th century.

12 The implementation finally happened in 2017, when the plaster casts of the sculptor Karla Vobišová Žáková were restored at the Academy of Fine Arts in the studio of Professor Petr Siegl. These models were taken to the HVH metalworking studio in Horní Kalná, led by brothers Pavel and Petr Horák. Wax models were made and divided into individual parts and cast from silver. Finally, the sculptural group was installed on a stone pedestal in the cathedral in 2018. Currently, there is a legal dispute for copyright to this statue, as one of the relatives of the mentioned author is trying to register for them. The lawyers of the Prague archbishopric stand against her.
} 
design supposed wooden doors, mainly due to their low weight. Flat bronze reliefs would be placed on them. The vestibule was composed of a large barred box at the head of the transept, in the corner there was designed a pillar with the archangel Michael, who created a support for the vestibule. The design won first place, although there were some objections to Wagner's sculptures, and therefore a new competition was announced. This time already architectural. And with the fact that Professor Sokol was invited, he demanded the participation of the sculptor (Wagner) and the common work could begin again.
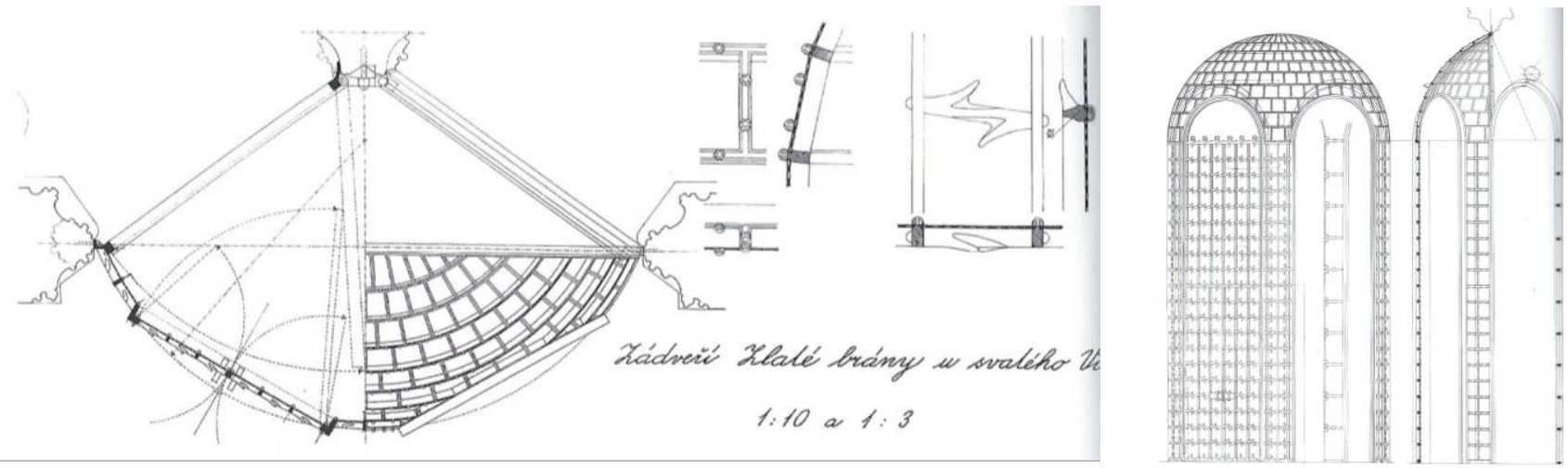

Fig. 7 and 8 - The final solution of the Golden Gate vestibule [9]
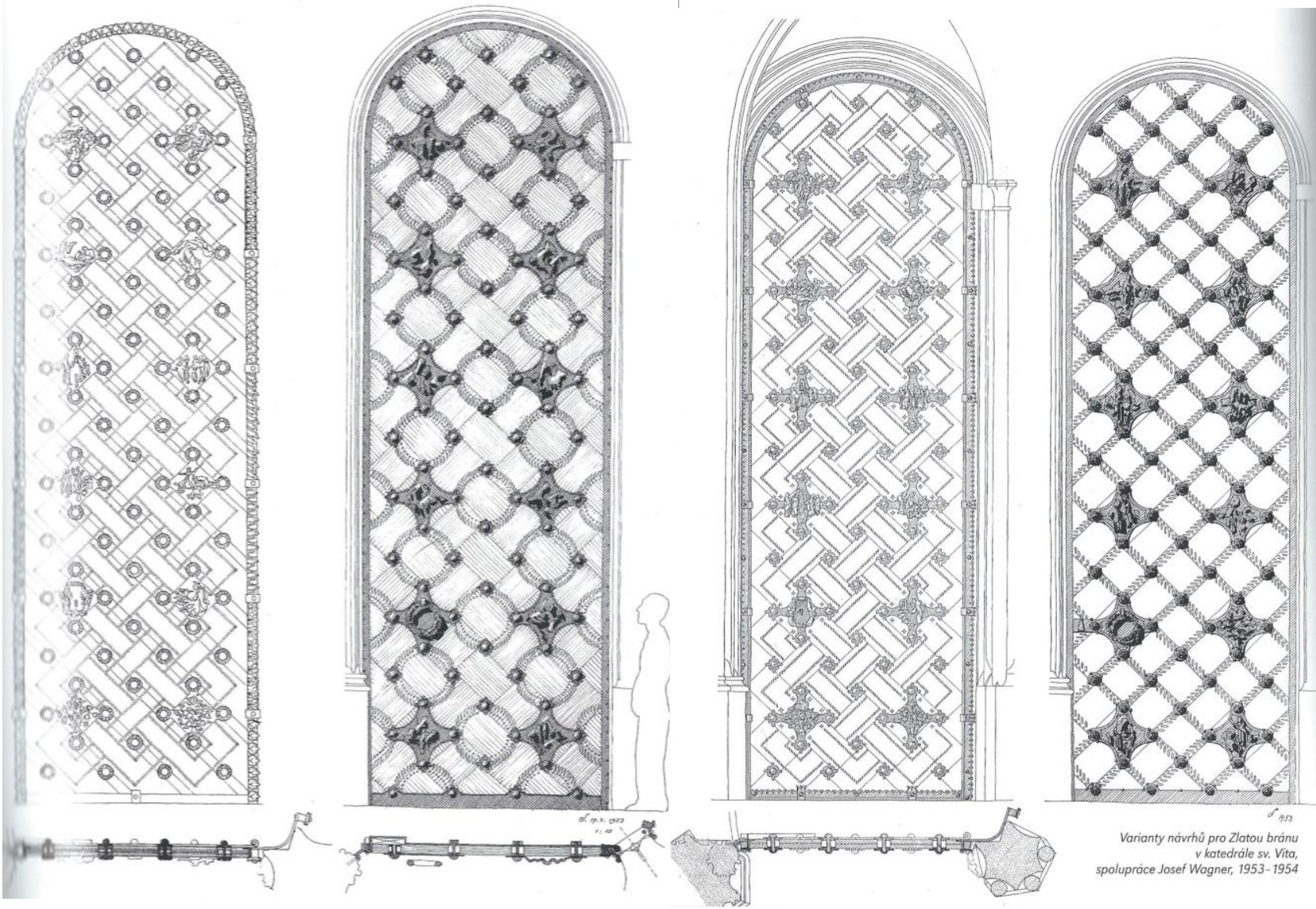

Fig. 9 - Options of plastic decoration of the Golden Gate door [10]

The vestibule was necessary, but also a weakness of the first design. Therefore, Sokol decided to hang the door on a stone pillar between the outer openings, so that when it opens, the 
wings fold in the middle. The vestibule will then be able to be flat, concave inwards and finished at the top by a small flat dome. The difficulty was that the stone pillar was very slight, but Sokol masterfully handled it by inserting a self-supporting metal cage into the stone frame. The cage inwards forms the glazed wall of the vestibule, on the other side the first door frame. After solving the vestibule, attention was focused on the door leaves. It should be wooden, and the sculptures would be attached to them like plaques. The construction of such large doors caused problems, and there were growing worries about the torsion of long woods, which were not sufficiently dry and would be exposed to different temperatures and humidity on each side. In the end, Sokol came up with the idea of constructing a door panel from short diagonal planks in a double layer, interleaved and connected by screw bolts. The most difficult task from Sokol's point of view was the plastic decoration. The choice of topic was not easy, because at this time the Union for the Completion of the Prague Cathedral had already been abolished and the project was paid by the President's Office, so the themes should not be too religious. The artists finally agreed to work on a New Testament parable. Wagner set about modelling with great zeal and enthusiasm, Sokol was still deciding how to place the reliefs on the smooth surface of the door. This activity was suspended by Wagner's death in 1957, and other sculptors told Sokol that they would like to continue working on it, but the professor decided to reject them all. One of the reasons was a certain pieta to a deceased friend. He decided to finish the door without the sculptures. The final and today's form is a smooth surface of wood, which is studded with variously shaped and gilded screw heads.

Sokol appreciated that this door looked naturally, as if it was from past periods. His attitude was beautifully expressed by the architect Karin Urbanová Kasanová in her doctoral dissertation: "Sokol's deep knowledge of history led him to a certain humbleness. His work becomes part of the complex, like small stones that make up a mosaic. The eye focuses on the complex and does not watch the small stones of the mosaic, until one is missing, people realize the loss. It is an approach that certainly does not lead to a star celebration of the architect's personality." [11]

\section{Working at the Castle in the 1960s and 1970s}

After the accession of President Antonín Novotný in 1957, a new concept of adaptation was made at Prague Castle. The architectural and construction aspect was reserved for the Association of Architects under the leadership of Jiři Gočár ${ }^{13}$, while the program and thought aspect was under the responsibility of the newly established Idea Council for the Modification of Prague Castle. It was decided that the architects would draw up an overall plan for the construction maintenance of the Castle, as it is called General. That is why, after many years, Sokol was asked to help with solving of the problems of Prague Castle. A new use was sought for unused buildings - the Burgrave's Office should be rebuilt into the House of Czechoslovak Children, the monastery of St. George to the Memorial of the Czechoslovak State and Lobkowitz Palace to the Palace of Labour. A multi-stage competition was announced for the mentioned General, in which various authors (Czech and Slovak) were invited, and therefore many unusable proposals appeared. One of the results was the initiative to build a new bridge from the Riding Hall to Hradčanské náměstí, which would create a new main entrance to the Castle. Smaller competition tasks were also announced and Sokol was invited to one of them. It was about building and colour modification of the southern facade of the Castle associated with the solution of utility and ceremonial lighting. Sokol did it dutifully and got this job. Based on this, Jiři Gočár offered him membership in the renewed committee of the Association of Architects for the renovation of the Castle. Sokol accepted and met

13 Jiř́ Gočár (June 12, 1913 - July 20, 1979) was a Czech architect, a graduate of Czech Technical University, the son of a famous architect, from 1949 to 1953 he was the head of the Stavoprojekt studio. He was later chairman of the Union of Architects. 
here with architects Jaroslav Fragner and Oldřich Starý, Professor Fuchs ${ }^{14}$ and historian Poch. ${ }^{15}$ The committee was chaired by Jiři Gočár. The idea council no longer met at this time. The modifications were discussed in the mentioned committee, and the architects were given a hearing, especially from Chancellor Novák. The above-mentioned large ideological projects were abandoned, only the House of Czechoslovak Children was realized. More specific intentions began to be preferred.

Modifications of the Old Palace were solved by a group consisting of Kotrba ${ }^{16}$, Poche and Studený. ${ }^{17}$ According to their data, a study was prepared within SÚRPMO, namely by architects Hlavatý ${ }^{18}$ and Matašovský. ${ }^{19}$ Professor Sokol received this study for assessment. He used this for an extensive tour of the whole building, he pointed out to the historical and artistic value of the building and warned that the proposed modifications are insufficient. Gočár therefore asked Sokol to draw up a new, larger study. Sokol was accepted into SÚRPMO because of this task. In this study, Sokol considered that it was necessary to distinguish and introduce four units that are above each other and together create the whole building - the Romanesque, early Gothic, high Gothic and late Gothic part. The visitors would then go through the individual restored layouts in chronological order. Everything should be graded by modifications of the Vladislav's building, which was used on ceremonial occasions at that time. The study, with the help of Burian ${ }^{20}$ and other experts, was completed within a year. It was soon approved, the implementation should happen gradually in several stages, but unfortunately nothing was implemented at all.

\footnotetext{
14 Bohuslav Fuchs (March 24, 1895 - September 18, 1972) was a Czech architect, town planner and theorist of considerable influence and European significance. One of the first pioneers of modern international style.

15 Emanuel Poche (October 8, 1903 - March 14, 1987) was a Czech art historian, assistant of Prof. Birnbaum, author of many professional and popular publications, member and one period chairman of the Club for Old Prague.

16 Viktor Kotrba (March 7, 1906 - September 3, 1973) was a Czech architect, historian of architecture, worker of historic preservation and art theorist.

17 Vladimír Studený (March 11, 1904 - February 19, 2005) was a Czech architect, painter. A conscientious archivist, thanks to whom many building drawings from the renovation of Prague Castle have been preserved.

18 Josef Hlavatý (March 19, 1923 - April 24, 2012) was a Czech architect, a student of Jan Sokol at the Academy of Arts, Architecture and Design in Prague. He collaborated long with architect Rothmayer and he was a member of the studio SÚRPMO 05.

19 Miloslav Matašovský (December 15, 1922 - 2004) was a Czech architect, author of theoretical studies and realizations of the regeneration of historic town cores (Prague, Teplice).

20 Jiří Burian ( ${ }^{*}$ February 1, 1935) is a Czech art historian, author of art publications and museological and exhibition realizations.
} 


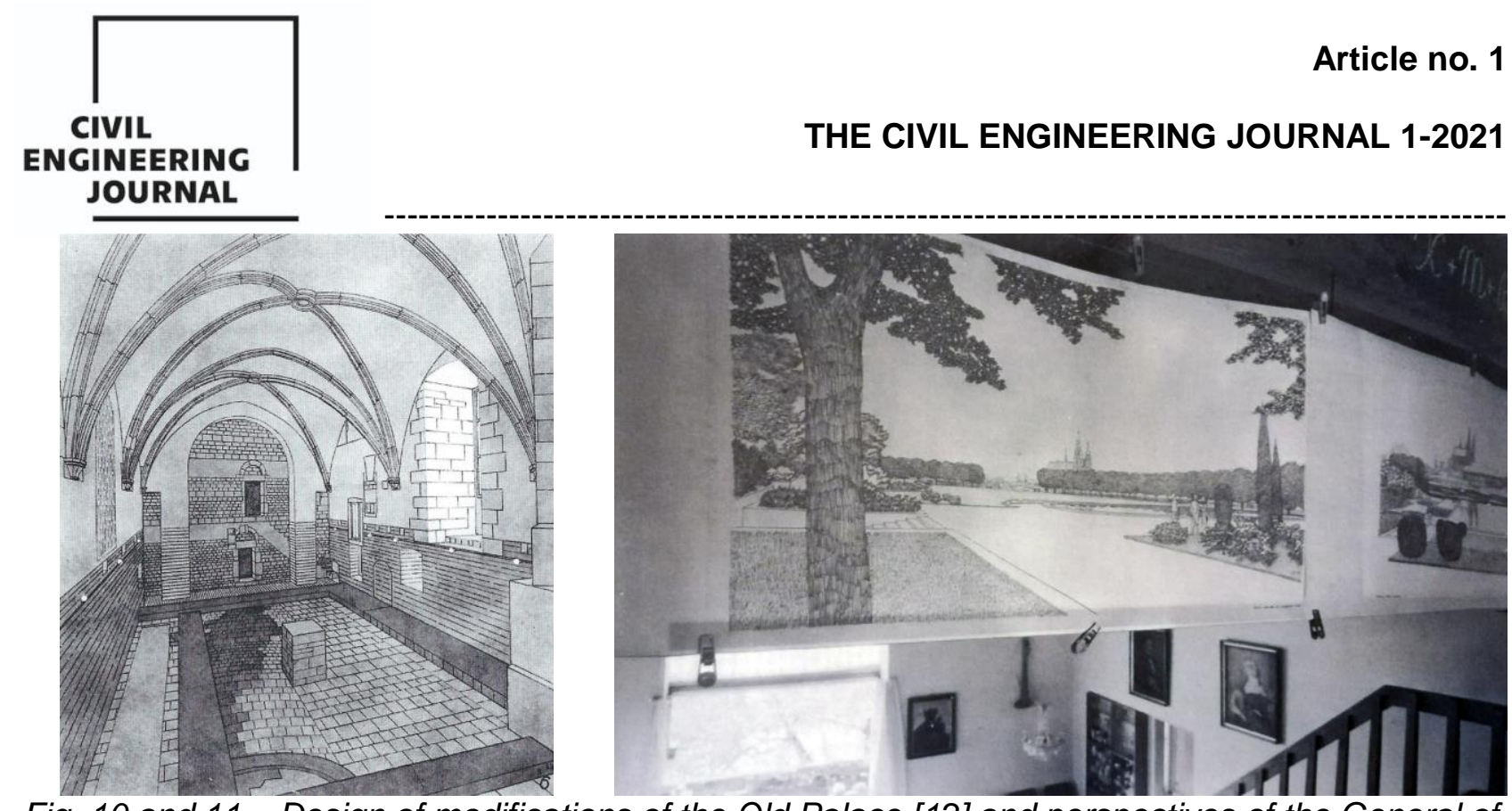

Fig. 10 and 11 - Design of modifications of the Old Palace [12] and perspectives of the General of Prague Castle [13]

The biggest task for Sokol was a plan for the modification of the entire area of Prague Castle, based on an urban solution through architectural details, design of lighting and greenery after solving technical requirements (heating, sewerage, low current, high current, etc.). It was a difficult task, as the castle is a large area with an important location, it was necessary to solve the traffic difficulties related to the Lesser Town and Petrín tunnel and the connection to the new transport solution in the surroundings. It was decided to withdraw from the plan to build a bridge between the Riding Hall and Hradcany square, even though an implementation project had already been prepared. Therefore, Sokol had to create a new concept of access ways to the Castle. There was also a creative task that corresponded with Sokol's town planning interest. It was about the consolidation and completion of castle parks and gardens. He worked hard on it, and he did most of it himself. Unfortunately, even in this case, the project was not implemented.

The General had three components. In the first of them - architectural part, Professor Sokol had prime position, in the second devoted to town planning he collaborated with Martin Krise ${ }^{21}$ and in the last technical part he left the management to his colleague Bašta, he retained only control authority. In the end, the whole General expanded in scope, it was developed from the originally architectural - town planning solution to a realization project with all the necessities, for example the schedule of implementation of works and costs associated with the implementation. It turned out that it would cost a lot of money, and Sokol soon realized that there would be no implementation again, and that was one of the reasons why he finally retired in 1976.

\section{Modifications to the interior of the cathedral}

One of the Sokol's last work was related to the Cathedral of St. Vitus, Wenceslas and Adalbert. Sokol held the idea that the cathedral is primarily the first church in the country, a sacred building. However, this did not correspond to the ideas of the then ruling regime, it preferred the concept of the cathedral as a museum of the dead periods, dead art, dead religion. The professor Sokol had long pointed out to the need for modifications caused mainly by liturgical reforms. The opportunity for a shift in this matter was the approaching millennial anniversary of the founding of the Prague bishopric in 1973. The appointment of a new archbishop Tomášek also contributed to the shift.

${ }^{21}$ Martin Krise $\left({ }^{*} 1942\right)$ is a Czech architect, town planner and preservationist, a member of the Club for Old Prague 
In his earlier (soon after the war) design, Sokol had considered moving the royal mausoleum to the northern arm of the cross nave, in front of the organ loft. A new main altar would be built in its place with the tomb of St. Adalbert. Therefore, a new nave would be released for ordinary but large masses. An older nave could be used for smaller gatherings. In the new plan, he followed up on the previous one, but gave up the idea of moving the mausoleum, instead he designed to use it as a divide between the new and older part and to serve as a backdrop for the new altar (according to liturgical reforms the altar should have the form of a table and ensure that the priest could celebrate the mass turned towards people). The new mensa should create the spiritual centre of the cathedral and within it would be located the tomb of St. Adalbert. A space for celebrants would be delimited around it. He had also devised visitor's flow during visitor's hours, when tourists should concentrate on the side naves and the centre of the cathedral would be closed to them. Sokol wrote an article about this, created a plan and perspective with an altar in the middle. All this was discussed with the Prague Archbishopric and general permission was given to the modifications.

Sokol imagined that the plan would be further developed and would be financed only from the resources of the archbishopric. However, this was not realistic in the that political situation, so Sokol's plan was forwarded to the President's Office by the Archbishop. There the plan was received very positively with regard to the fact that various temporary solutions would be cancelled, but it depended very much on the opinion of the preservation commission, headed by academician Filip. ${ }^{22}$ However, he did not have the prime position in similar matters, so Sokol went to see other members - Poch and Kotrba, whom he had known from earlier times. At an informal meeting, they agreed with Sokol, liked his plan and promised him support, but when the official meeting of the preservation commission took place, everything turned around. At least Poche was silent, but Kotrba suddenly disagreed with the placement of the mensa in front of the mausoleum (which was the main idea of the design). So that meant stopping this project.

Fortunately, it did not take long period and Sokol was commissioned to design a new altar according to regulations of the Second Vatican Council (i.e. the altar should be turned towards people). For this purpose, the extension of the choir platform was fitting, the new altar could be placed on a new part of the platform together with the rood screen and the cross. In front of the platform, new staircases leading to the side naves were created, and thus the original relation between the choir of St. Vitus and the mentioned naves and the royal oratory. He decided to use the extended grade of Mocker's altar for the bishop's throne. Sokol tried to extend this task to the reconstruction of the entire choir, which clearly shows the effort to save something from his earlier study. He did not like Mocker's altar, but he was forced to keep it, so he wanted to use it at least as a backdrop for the cathedra. Behind this altar there was a stone spiral staircase leading to the little upper tower, where the monstrance was previously exhibited (but at that time the little towers were no longer used). Between the altar and the saint's tomb, a church back area was formerly established, there were brooms, candlesticks, carpets and ladders. Sokol tried to restore the dignity of this place and therefore proposed to remove Mocker's staircase, the cabinets for church equipment behind the grave, Max's statue of St. Vitus, which stood on the tomb like on a pedestal. In terms of restoring the original architectural idea, he decided to relocate the altar of St. Vitus from the gallery to the original place in the high choir. This would loosen the end of the cathedral that the decorative Parlér's consoles would be noticeable, even from the cathedral gallery. This was presented to the preservationists at the Castle and initially accepted positively again, but Poche did not take part in the meeting and he unfortunately persuaded the commission to adjust its positive opinion and Sokol was again defeated.

22 Jan Filip (December 25, 1900 - April 30, 1981) was a Czech archaeologist and historian, professor at Charles University, in 1963-74 he was the director of the Archaeological Institute of the Czechoslovak Academy of Sciences. 


\section{$\prod_{\substack{\text { CIVIL } \\ \text { ENGINEERING }}}$ \\ JOURNAL}

Article no. 1

THE CIVIL ENGINEERING JOURNAL 1-2021
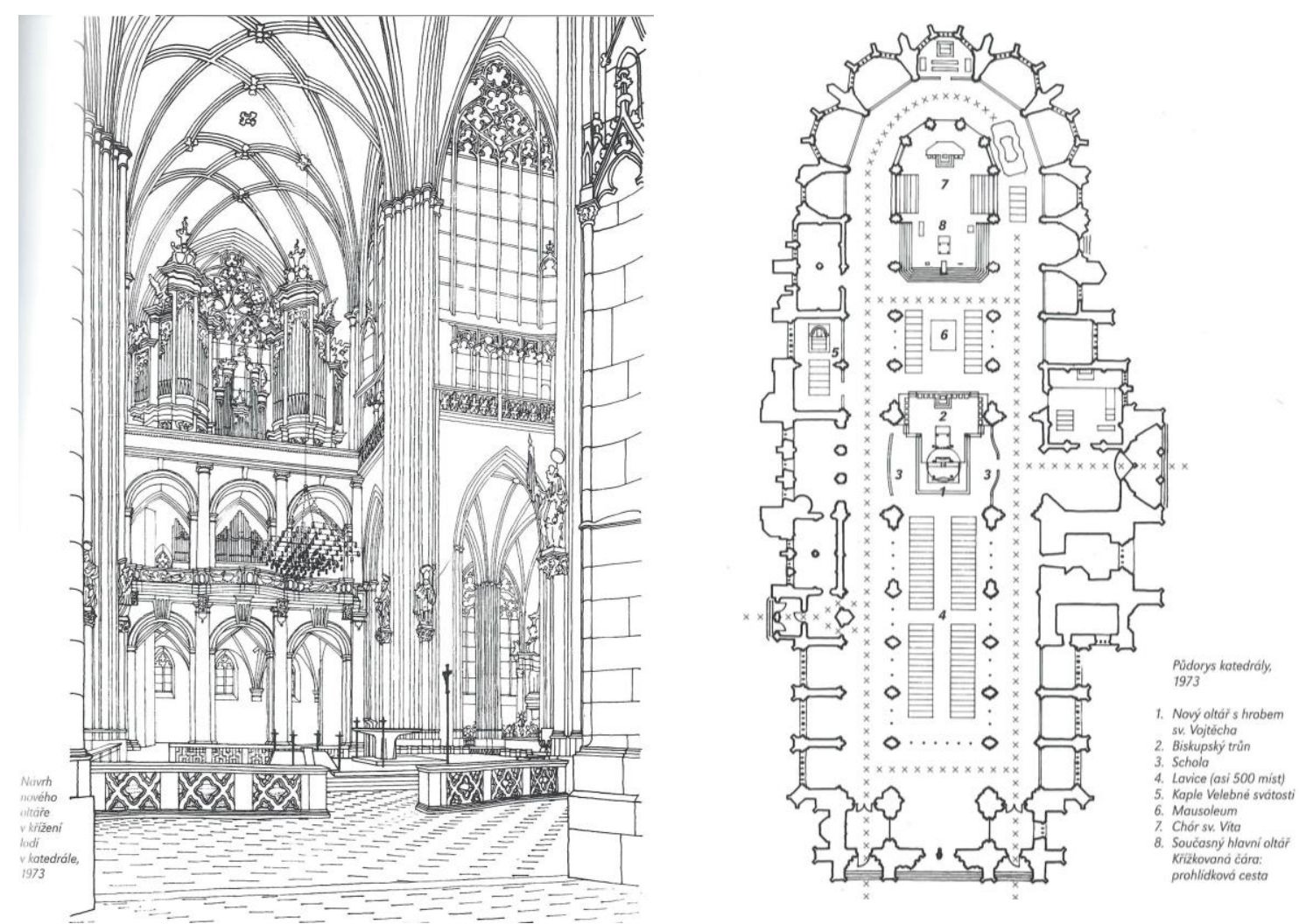

Fig. 12 and 13-Perspective of the new altar at the crossing of naves [14] and designed floor plan of the cathedral [15]

In the end, he was only allowed to prepare a new mensa. The altar slab was designed from marble which was supported by six legs made of gilded steel I profiles. The altar was made, but instead of a marble slab, a Romanian limestone slab was used.

\section{CONCLUSION}

Architect Sokol was and still is an inspiring person who was active in the field of historic preservation. Although the number of his realizations is not considerable, thanks to his written memories and documents it is possible to deal with the whole breadth of his projects.

His work showed a deep knowledge of the construction of the historical buildings and history of art, which resulted in his humble approach to projects related to the restoration of monuments. Although he did not originally want to pursue the career of a preservationist, because it was more of a clerical position, over time he came to like this work, because he could apply his creativity, spiritual foundation and town planning principles, which interested him from a young age. In his work, he tried to find new ways and approaches (in which he tried to get closer to Le Corbusier, August Perret and others). He emphasized the emotional and spiritual side of human perception and experience of architecture. He took it as a success, if his interventions in historical architecture were perceived as a natural part of the complex, he did not want to exhibit unnecessarily.

Professor Sokol was a generally gifted architect with an overlap to various fields. He has influenced (not only during his school activity at the Academy of Arts, Architecture and Design in Prague) many other architects, and above all the ideological and intellectual basis of his designs is comprehensive and precise. Therefore, it is clearly a loss that many of his ideas did not realize for various reasons. 


\section{ACKNOWLEDGEMENTS}

This arcticle was written within the subject Historical Buildings in Contemporary Conditions, which is taught by Professor Mikuláš Hulec at the Faculty of Civil Engineering of CTU in Prague.

\section{REFERENCES}

[1] Sokol J., Sokol V., 2004. Moje plány: paměti architekta, 113 (Triáda) 344 pp.

[2] Sokol J., Sokol V., 2004. Moje plány: paměti architekta, 133 (Triáda) 344 pp.

[3] Sokol J., Sokol V., 2004. Moje plány: paměti architekta, 206 (Triáda) 344 pp.

[4] Sokol J., Sokol V., 2004. Moje plány: paměti architekta, 207 (Triáda) 344 pp.

[5] Sokol J., Sokol V., 2004. Moje plány: paměti architekta, 272-273 (Triáda) 344 pp.

[6] Sokol J., Sokol V., 2004. Moje plány: paměti architekta, 164 (Triáda) 344 pp.

[7] Sokol J., Sokol V., 2004. Moje plány: paměti architekta, 235 (Triáda) 344 pp.

[8] Sokol J., Sokol V., 2004. Moje plány: paměti architekta, 238 (Triáda) 344 pp.

[9] Sokol J., Sokol V., 2004. Moje plány: paměti architekta, 242 (Triáda) 344 pp.

[10] Sokol J., Sokol V., 2004. Moje plány: paměti architekta, 239-240 (Triáda) 344 pp.

[11] Urbanová Kasanová K., 2010. Tvưrčí proces architekta Jana Sokola, 76 (ČVUT v Praze, Fakulta architektury) $344 \mathrm{pp}$.

[12] Sokol J., Sokol V., 2004. Moje plány: paměti architekta, 211 (Triáda) 344 pp.

[13] Sokol J., Sokol V., 2004. Moje plány: paměti architekta, 212 (Triáda) 344 pp.

[14] Sokol J., Sokol V., 2004. Moje plány: paměti architekta, 251 (Triáda) 344 pp.

[15] Sokol J., Sokol V., 2004. Moje plány: paměti architekta, 252 (Triáda) 344 pp. 